\title{
Ultrasonography of the Peripheral Nerves of the Forearm, Wrist and Hand: Definition of Landmarks, Anatomical Correlation and Clinical Implications
}

\section{Ultraschall der peripheren Nerven an Unterarm, Handgelenk und Hand: Definition von Landmarken, anatomische Korrelation und klinische Bedeutung}

Authors

Leonhard Gruber ${ }^{1}$, Alexander Loizides ${ }^{1}$, Siegfried Peer $^{2}$, Lisa Maria Walchhofer ${ }^{1}$, Verena Spiss ${ }^{1}$, Erich Brenner ${ }^{3}$, Kathrin Stahl ${ }^{4}$, Hannes Gruber ${ }^{1}$

Affiliations

1 Department of Radiology, Medical University of Innsbruck, Austria

2 Department of Radiology, B7-Institute, Innsbruck, Austria

3 Department of Anatomy, Histology and Embryology, Medical University of Innsbruck, Austria

4 Dentistry, Ordination Dr. Schöning, Kufstein, Austria

Key words

ultrasound, anatomy, nervous-peripheral, hand

received 11.09.2019

accepted 27.01.2020

Bibliography

Fortschr Röntgenstr 2020; 192: 1060-1072

Published online: 4.3.2020

DOI 10.1055/a-1110-7508

ISSN 1438-9029

(C) 2020. Thieme. All rights reserved.

Georg Thieme Verlag KG, Rüdigerstraße 14,

70469 Stuttgart, Germany

Correspondence

Dr. Lisa Maria Walchhofer

Radiology, Medizinische Universität Innsbruck,

Anichstrasse 35, 6020 Innsbruck, Austria

Tel.: ++43/51250480303

lisa-maria.walchhofer@tirol-kliniken.at

\section{ZUSAMMENFASSUNG}

Hintergrund Periphere Nervenpathologien an der oberen Extremität werden zunehmend mittels hochauflösenden Ultraschalls (HRUS) untersucht, wobei die zügige Identifikation bestimmter Nervensegmente durch geringe Nervendurchmesser und komplexe regionale Anatomie erschwert sein kann. Landmarken könnten hier die Zeiteffizienz sowie Beurteilbarkeit in der entsprechenden Region verbessern.

Methode Relevante Landmarken und Schnittebenen für 11 Nervensegmente an Unterarm, Handgelenk und Hand wurden an Leichenarmen mittels HRUS definiert. Anschließend wurden korrelierende Gefrierschnitte und topografische neurovaskuläre Präparationen durchgeführt. Dieser Artikel bietet anatomische Schnitte, topografische Erläuterungen sowie hochauflösende sonoanatomische Korrelationen der beschriebenen Nervensegmente. Zudem wurde das erfolgreiche Auffinden der Nervensegmente anhand der Landmarken an 20 gesunden Probanden evaluiert.

Ergebnisse und Schlussfolgerung Sonografische Landmarken und Anleitungen für die rasche Identifikation und Beurteilung von peripheren Nerven von Unterarm, Handgelenk und Hand werden in sonoanatomisch-korrelierender sowie in tabellarischer Form unter Berücksichtigung von Normvarianten präsentiert. Das Erlernen der peripheren Nervensonografie sowie die diagnostische Beurteilung und gegebenenfalls therapeutische Intervention der entsprechenden Nerven sollen anhand dieses Manuskripts erleichtert werden.

\section{Kernaussagen:}

- Hochauflösender Ultraschall ermöglicht die Untersuchung von peripheren Nerven an Unterarm, Handgelenk und Hand.

- Anatomische Landmarken erleichtern und beschleunigen das Auffinden und die Evaluierung dieser Nervenäste.

- Mit der Landmark-basierten Herangehensweise lassen sich hohe Detektionsraten der Nervenäste erzielen.

\section{ABSTRACT}

Background Peripheral nerve pathologies of the upper extremity are increasingly assessed by high-resolution ultrasonography (HRUS), yet rapid identification of nerve segments can be difficult due to small nerve diameters and complex regional anatomy. We propose a landmark-based approach to speed up and facilitate evaluation and intervention in this region.

Method Relevant landmarks and section planes for eleven nerve segments of the forearm, wrist and hand were defined by ultrasonography in cadaver arms before cryosection and topographical neurovascular preparation. Information on all nerve segments and a pictorial guide including anatomical cross-sections, topographical preparations and HRUS images 
are provided. The identification rates of these nerve segments were then assessed in 20 healthy volunteers.

Results and Conclusion Sonographic landmarks and guidelines for the rapid identification and assessment of nerves of the forearm, wrist and hand are presented in pictorial and tabular form, including discussion of normal variants. Utilizing this overview should facilitate training, diagnostic examinations and intervention for nerves of the upper extremity.

\section{Key Points:}

- High-resolution ultrasound enables assessment of peripheral nerves of the forearm, wrist and hand.
- A landmark-based approach can facilitate and speed up nerve evaluation in these regions.

- High detection rates could be reproduced using the proposed landmark-based approach.

\section{Citation Format}

- Gruber L, Loizides A, Peer S et al. Ultrasonography of the Peripheral Nerves of the Forearm, Wrist and Hand: Definition of Landmarks, Anatomical Correlation and Clinical Implications. Fortschr Röntgenstr 2020; 192: 1060-1072

\section{Introduction}

Peripheral nerve pathologies of the forearm, wrist and hand can stem from a myriad of causes, such as compression, direct and indirect trauma, tumors and scar tissue [1]. While thorough history taking and clinical examination can help to narrow down the location of neural damage, further examinations are necessary to exactly locate the site of damage and define the cause: in this context electrophysiological studies [2] can only determine the approximate location of neural damage and gather information as to whether sensory or motor neuron, demyelinating or axonal damage predominates. The causative mechanisms cannot be identified in the early course of the disease in numerous cases. Thus, an appropriate therapeutic concept may not be deduced in a timely fashion.

High-resolution ultrasound (HRUS), on the other hand, which is increasingly used in the diagnosis of peripheral neuropathies due to its high resolution and low technical requirements, allows for rapid identification of the location and causative mechanisms of neural damage [1,3]. Technical advances enable depiction and assessment of tiny nerves and nerve branches [4, 5]. Nonetheless, successful identification of the location and assessment of small nerve branches mostly rely on thorough knowledge of human topography of the peripheral nerves. Following the course of peripheral nerves and nerve branches distally from a main stem is time consuming and can be hindered by nerve segments not being sufficiently accessible to HRUS due to surrounding anatomic structures, by variations in branching patterns or by masking tissue alterations, such as scar tissue or hematoma. Anatomical landmarks can be employed to quickly identify distal nerve branches and possible lesions.

The aims of this study were to define standard sonoanatomic landmarks for the peripheral nerves of the forearm, wrist and hand in two embalmed cadavers as a prerequisite and to evaluate these landmarks in a prospective study in 20 healthy volunteers.

\section{Materials and methods}

\section{Anatomical studies}

HRUS of two cadaver forearms was performed on a Philips iU22 with a $17-5 \mathrm{MHz}$ broadband linear transducer (Philips, Washing- ton, USA) before preparation or cryosection to define eight section planes with relevant branching of the median, ulnar and radial nerve ( $\triangleright$ Fig. 1$)$. Intracutaneous sutures were then applied to define exact planes for preparation or cryosection.

All cadavers at the institutional Department for Anatomy \& Embryology were from participants who voluntarily donated their bodies for teaching and research [6]. Cadavers were preserved in a carbol-formalin solution for at least 1 year $[7,8]$. Two cadaver arms from one donor were selected for preparations. Preparations of the left arm involved removal of the cutis, subcutaneous tissue and muscle fasciae and mobilization of the muscles. Utmost care was taken to preserve the neurovascular structures and muscle tendons. Relevant anatomical structures surrounding the neural

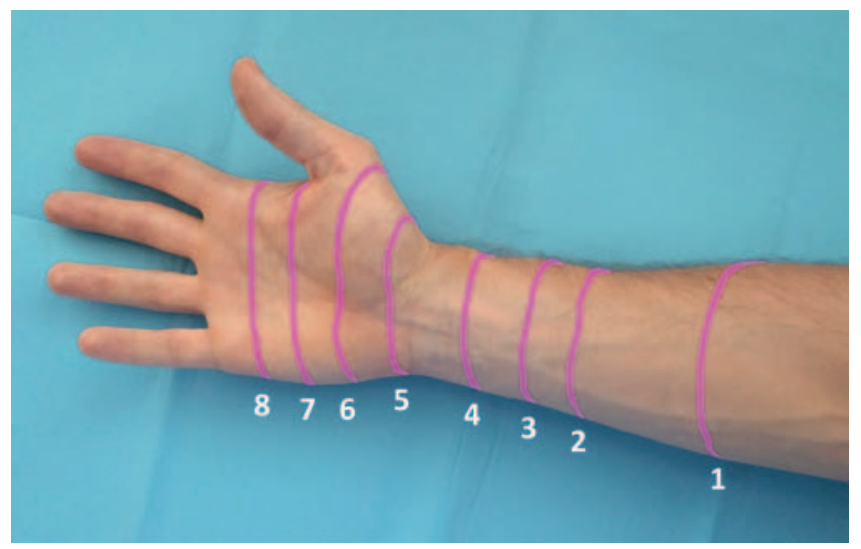

- Fig. 1 Predefined section planes by ultrasound (see also $>$ Table 1) with pink lines at the predefined nerve segments: (1) proximal superficial branch of the radial nerve, (2) dorsal branch of the ulnar nerve, (3) distal superficial branch of the radial nerve, (4) palmar branch of the median nerve, (5) branching of the ulnar nerve in Gyon's canal, (6) thenar branch of the median nerve, (7) common digital palmar nerves and (8) branching into proper digital nerves.

- Abb. 1 Vordefinierte Schallkopfpositionen (siehe auch $>$ Tab. 1) mit pinken Linien an den vordefinierten Nervensegmenten: (1) proximaler Ramus superficialis des N. radialis, (2) Ramus dorsalis des N. ulnaris, (3) distaler Ramus superficialis des N. radialis, (4) Ramus palmaris des N. medianus, (5) Aufzweigung des N. ulnaris in der Guyon'schen Loge, (6) Thenar Ast des N. medianus, (7) Nn. digitales palmares communes, (8) Aufzweigung in die Nn. Digitales palmares proprii. 
- Table 1 List of nerves of the upper extremity including information on transducer positioning and relevant landmarks.

- Tab. 1 Liste der Nerven an der oberen Extremität mit Informationen zur Schallkopfpositionierung und relevanten Landmarken.

\begin{tabular}{|c|c|c|c|}
\hline nerve & nerve branch & sonographic guidelines & anatomical landmarks \\
\hline \multirow[t]{3}{*}{ radial nerve } & $\begin{array}{l}\text { superficial branch } \\
\text { (proximal) }\end{array}$ & $\begin{array}{l}\text { place transducer at the transition from } \\
\text { proximal to middle third of radial } \\
\text { forearm. }\end{array}$ & $\begin{array}{l}\text { palmar: tendon of brachioradialis muscle } \\
\text { medial: radial vessels } \\
\text { dorsal: tendons of long and short extensor carpi } \\
\text { radialis muscles }\end{array}$ \\
\hline & $\begin{array}{l}\text { superficial branch } \\
\text { (distal) }\end{array}$ & $\begin{array}{l}\text { place transducer } 5 \mathrm{~cm} \text { proximal to the } \\
\text { radial foveola at the radial edge of the } \\
\text { forearm. }\end{array}$ & $\begin{array}{l}\text { radial: tendon of brachioradialis muscle } \\
\text { dorsal: extensor carpi radialis longus distal: } \\
\text { abductor pollicis longus }\end{array}$ \\
\hline & $\begin{array}{l}\text { deep branch } \\
\text { (proximal) }\end{array}$ & $\begin{array}{l}\text { locate the proximal border of the } \\
\text { supinator muscle, the nerve can be } \\
\text { found running underneath. }\end{array}$ & $\begin{array}{l}\text { distal: proximal border of the supinator muscle. } \\
\text { Palmar: supinator muscle BELLY, arch of Frohse }\end{array}$ \\
\hline \multirow[t]{7}{*}{ ulnar nerve } & dorsal branch & $\begin{array}{l}\text { place transducer at the ulnar edge of } \\
\text { forearm } 3-5 \mathrm{~cm} \text { proximal to the ulnar } \\
\text { head. }\end{array}$ & $\begin{array}{l}\text { palmar: tendon of the flexor carpi ulnaris muscle } \\
\text { dorsal: tendon of the extensor carpi ulnaris } \\
\text { muscle and distal ulna }\end{array}$ \\
\hline & $\begin{array}{l}\text { main stem (Gyon's } \\
\text { canal) }\end{array}$ & $\begin{array}{l}\text { place transducer at the linea carpis pal- } \\
\text { maris distalis over the pisiform bone. }\end{array}$ & $\begin{array}{l}\text { palmar: palmar aponeurosis and palmaris brevis } \\
\text { muscle } \\
\text { dorsal: retinaculum flexorum } \\
\text { ulnar: pisiform bone }\end{array}$ \\
\hline & palmar branch & $\begin{array}{l}\text { place transducer } 3 \mathrm{~cm} \text { proximal to the } \\
\text { pisiform bone. }\end{array}$ & accompanied by main ulnar nerve stem. \\
\hline & superficial branch & $\begin{array}{l}\text { place transducer distal to the pisiform } \\
\text { bone in transverse orientation. }\end{array}$ & $\begin{array}{l}\text { proximal: outlet of Gyon's canal } \\
\text { dorsal: pisohamate ligament } \\
\text { palmar: palmaris brevis muscle }\end{array}$ \\
\hline & deep branch & $\begin{array}{l}\text { place transducer distal to the pisiform } \\
\text { bone in transverse orientation. }\end{array}$ & $\begin{array}{l}\text { proximal: outlet of Gyon's canal } \\
\text { palmar: pisohamate ligament } \\
\text { ulnar: abductor digiti minimi } \\
\text { radial: short flexor digiti minimi } \\
\text { accompanied by the deep palmar arch }\end{array}$ \\
\hline & $\begin{array}{l}\text { common palmar } \\
\text { finger nerves }\end{array}$ & $\begin{array}{l}\text { place transducer over the radial wrist at } \\
\text { the height of the pisiform bone parallel } \\
\text { to the distal linea carpi palmaris. }\end{array}$ & $\begin{array}{l}\text { distal: pisiform bone } \\
\text { palmar: pisohamate ligament } \\
\text { dorsal: tendons of the superficial flexor digitorum } \\
\text { muscles, lumbrical muscles }\end{array}$ \\
\hline & $\begin{array}{l}\text { proper palmar finger } \\
\text { nerves }\end{array}$ & $\begin{array}{l}\text { place transducer on the proximal } \\
\text { phalanges. }\end{array}$ & $\begin{array}{l}\text { dorsal: finger artery } \\
\text { radial/ulnar: phalanges }\end{array}$ \\
\hline \multirow[t]{4}{*}{ median nerve } & palmar branch & $\begin{array}{l}\text { place transducer } 3-5 \mathrm{~cm} \text { proximal of } \\
\text { the linea carpi palmaris distalis at the } \\
\text { anterior forearm. }\end{array}$ & $\begin{array}{l}\text { radial: tendon of the flexor carpi radialis and radial } \\
\text { artery } \\
\text { ulnar: tendon of the palmaris longus muscle } \\
\text { (if present) and flexor digitorum superficialis } \\
\text { (deeply located) }\end{array}$ \\
\hline & thenar branch & $\begin{array}{l}\text { place transducer over and parallel to the } \\
\text { thenar crease (linea vitalis). }\end{array}$ & $\begin{array}{l}\text { palmar: flexor retinaculum and palmar } \\
\text { aponeurosis (palmar) } \\
\text { radial: tendon of the flexor carpi radialis and } \\
\text { flexor pollicis longus muscle (deeply located) } \\
\text { ulnar: common digital nerves, stemming from } \\
\text { the median nerve }\end{array}$ \\
\hline & $\begin{array}{l}\text { common palmar fin- } \\
\text { ger nerves }\end{array}$ & $\begin{array}{l}\text { place transducer on a connecting line } \\
\text { between the scaphoid and pisiform } \\
\text { bones. }\end{array}$ & $\begin{array}{l}\text { radial: thenar muscles } \\
\text { palmar: flexor retinaculum } \\
\text { dorsal: tendons of the superficial flexor digitorum } \\
\text { muscles, lumbrical muscles }\end{array}$ \\
\hline & $\begin{array}{l}\text { proper palmar finger } \\
\text { nerves }\end{array}$ & $\begin{array}{l}\text { place transducer on the proximal } \\
\text { phalanges. }\end{array}$ & $\begin{array}{l}\text { dorsal: finger artery } \\
\text { radial/ulnar: phalanges }\end{array}$ \\
\hline
\end{tabular}



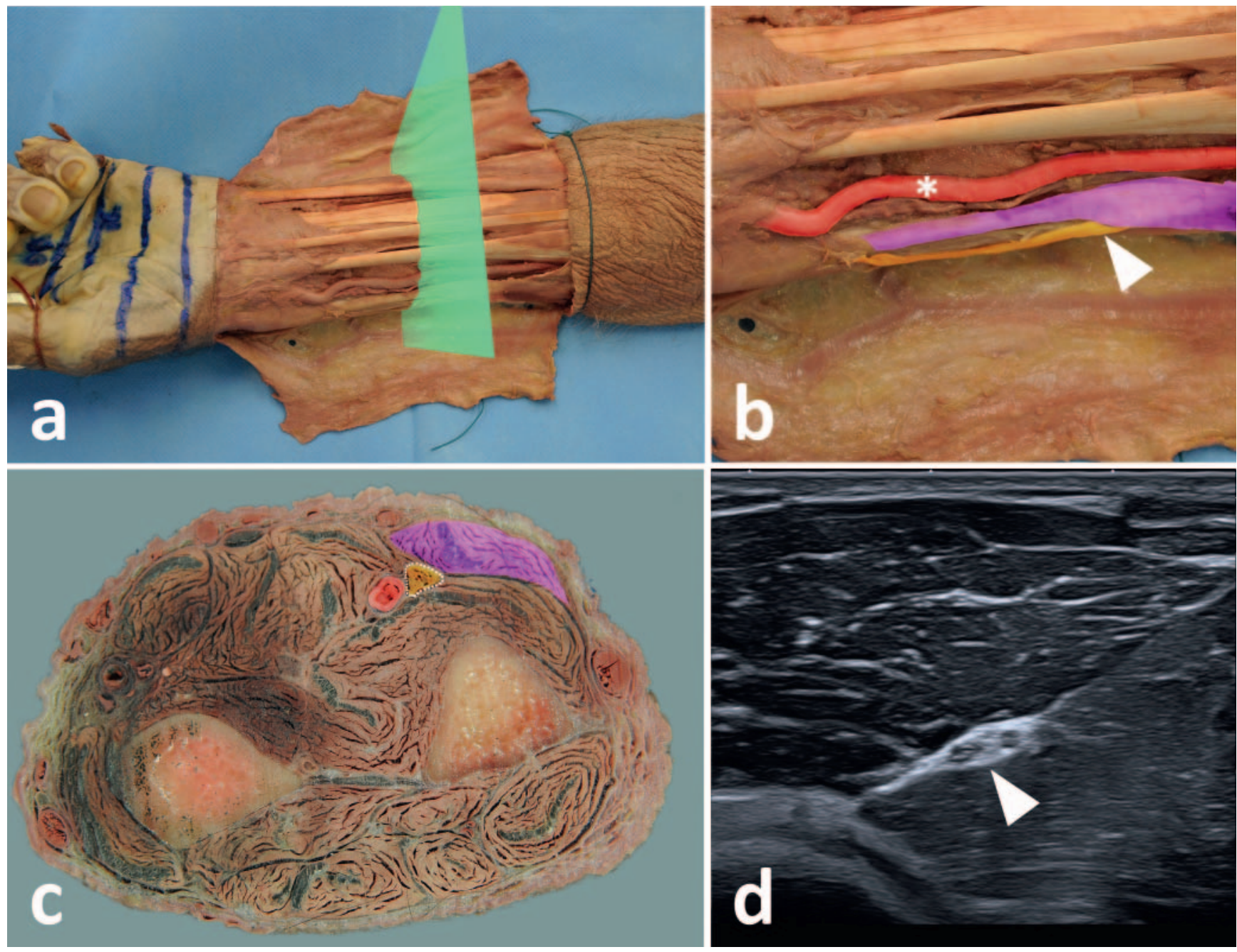

- Fig. 2 Proximal segment of the superficial branch of the radial nerve: anatomical preparation overview a, color-highlighted magnification $\mathbf{b}$, anatomical cross-section $\mathbf{c}$, and corresponding high-resolution ultrasound image $\mathbf{d}$. The proximal segment of the superficial branch of the radial nerve (yellow, white arrowhead) can be seen crossing under the tendon of the brachioradial muscle (purple). Radial artery (red, *).

- Abb. 2 Proximales Segment des Ramus superficialis N. radialis: anatomische Präparation a, eingefärbte Vergrößerungsaufnahme b, anatomischer Schnitt c, korrespondierendes hochauflösendes Ultraschallbild d. Das proximale Segment des R. superficialis N. radialis (gelb, weißer Pfeilkopf) unterkreuzt die Sehne des M. brachioradialis (violett). A. radialis (rot, * ).

branches that could act as potential landmarks were then defined including muscle bellies, tendons, bones and vessels. Frozen sections $\left(-20^{\circ} \mathrm{C}\right)$ of the right arm were then performed at eight predefined segments. To avoid tissue distortion due to thawing, photo documentation was performed immediately after cryosection with a Nikon D300S (Nikon; Tokyo, Japan).

\section{Validation of landmarks in healthy volunteers}

To assess the validity of the landmarks defined in the two cadaver arms, both arms in 20 healthy volunteers (10 female, 10 male; average age: $33 \pm 9.9$ years, range: $25-54$ years) were examined using a Philips iU22 with a $17-5 \mathrm{MHz}$ linear transducer (Philips, Washington, USA) and a $1 \mathrm{~cm}$ gel stand-off pad (Geistlich Pharma; Wollhusen, Switzerland). The exclusion criteria were prior surgery, recent trauma of the upper extremity, known acute or chronic neuropathies such as CTS or other compression neuropathies and neurogenic pain syndrome. All volunteers provided written consent and the examinations were performed in accordance with the declaration of Helsinki [9]. All data was collected anonymously. The examiners S.P. and V.S. had over 10 and 5 years of experience in musculoskeletal sonography, respectively.

The examiners worked in consensus following this schedule: First, the predefined landmarks from the cadaver study were identified and then the detectability of the relevant nerve segment was assessed as sufficient or insufficient.

\section{Landmark-based anatomy}

\section{Radial nerve}

The superficial branch ( $R$. superficialis $n$. radialis) runs medially along the brachioradial muscle and reaches the back of the hand, 

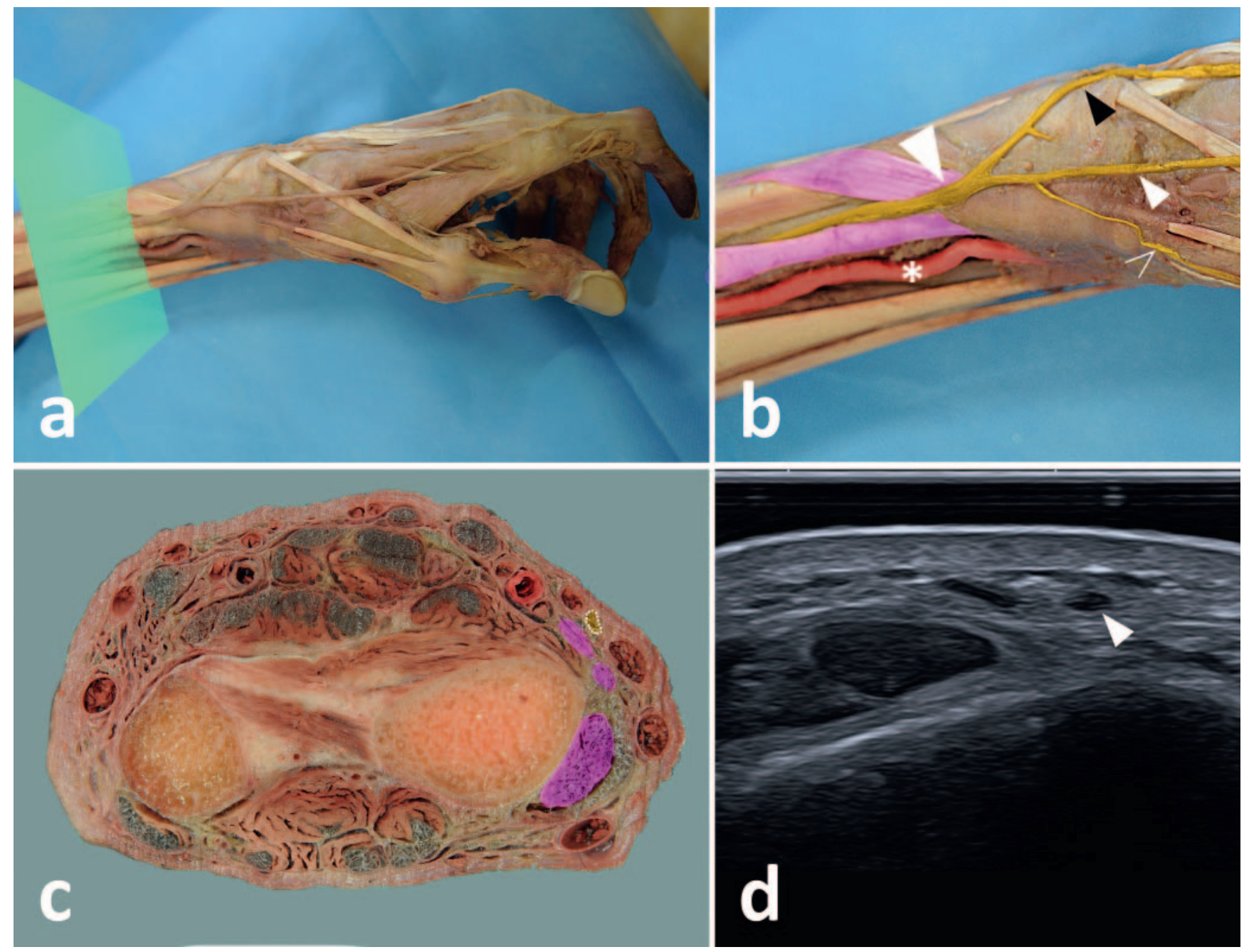

- Fig. 3 Distal segment of the superficial branch of the radial nerve: anatomical preparation overview a, color-highlighted magnification b, anatomical cross-section c, and corresponding high-resolution ultrasound image $\mathbf{d}$. Distal segment of the superficial branch of the radial nerve (yellow) with its branches to the dorsal first digit (empty white arrowhead), second digit (white arrowhead) and third digit (black arrowhead). Radial artery (red, *).

- Abb. 3 Distales Segment des Ramus superficialis N. radialis: anatomische Präparation a, eingefärbte Vergrößerungsaufnahme b, anatomischer Schnitt c, korrespondierendes hochauflösendes Ultraschallbild d. Distales Segment des R. superficialis N. radialis (gelb) mit Ästen zum dorsalen Daumen (leerer weißer Pfeilkopf), zweiten Finger (weißer Pfeilkopf) und dritten Finger (schwarzer Pfeilkopf). A. radialis (rot, ${ }^{*}$ ).

giving off the dorsal digital nerves (Nn. digitales dorsales). An infrequent anastomosis to the ulnar nerve is known as Ramus communicans cum ulnare $[10,11]$.

Structures along the proximal superficial branch are anteriorly the tendon of the brachioradial muscle, laterally the radial vessels and dorsally the tendons of the extensor carpi radialis brevis and longus muscles. At the distal forearm, the nerve can be found subcutaneously at the dorsal side of the forearm giving off branches to the thumb, index, middle and ring finger.

The proximal superficial branch can be identified when positioning the transducer at the transition from the proximal to middle third of the forearm. The nerve can be found running along the tendons of the brachioradialis and extensor carpi radialis longus and brevis muscles ( $\triangleright$ Fig. 2 ).
The distal part can be located around $5 \mathrm{~cm}$ proximal to the radial foveola at the radial edge of the radius. The nerve is located anterior to the tendons of the extensor carpis radialis longus muscle, dorsal to the brachioradialis tendons and the radial vessels and atop the tendon of the abductor pollicis longus muscle, which it crosses over at the height of the styloid process of the radius $(\triangleright$ Fig.3). After crossing the radial foveola the dorsal digital nerves originate.

The deep branch of the radial nerve ( $R$. profundus $n$. radialis) runs underneath the supinator muscle giving off small muscle branches and reaching the wrist as the posterior interosseous nerve. The nerve can be found most easily at the proximal border of the supinator muscle. 

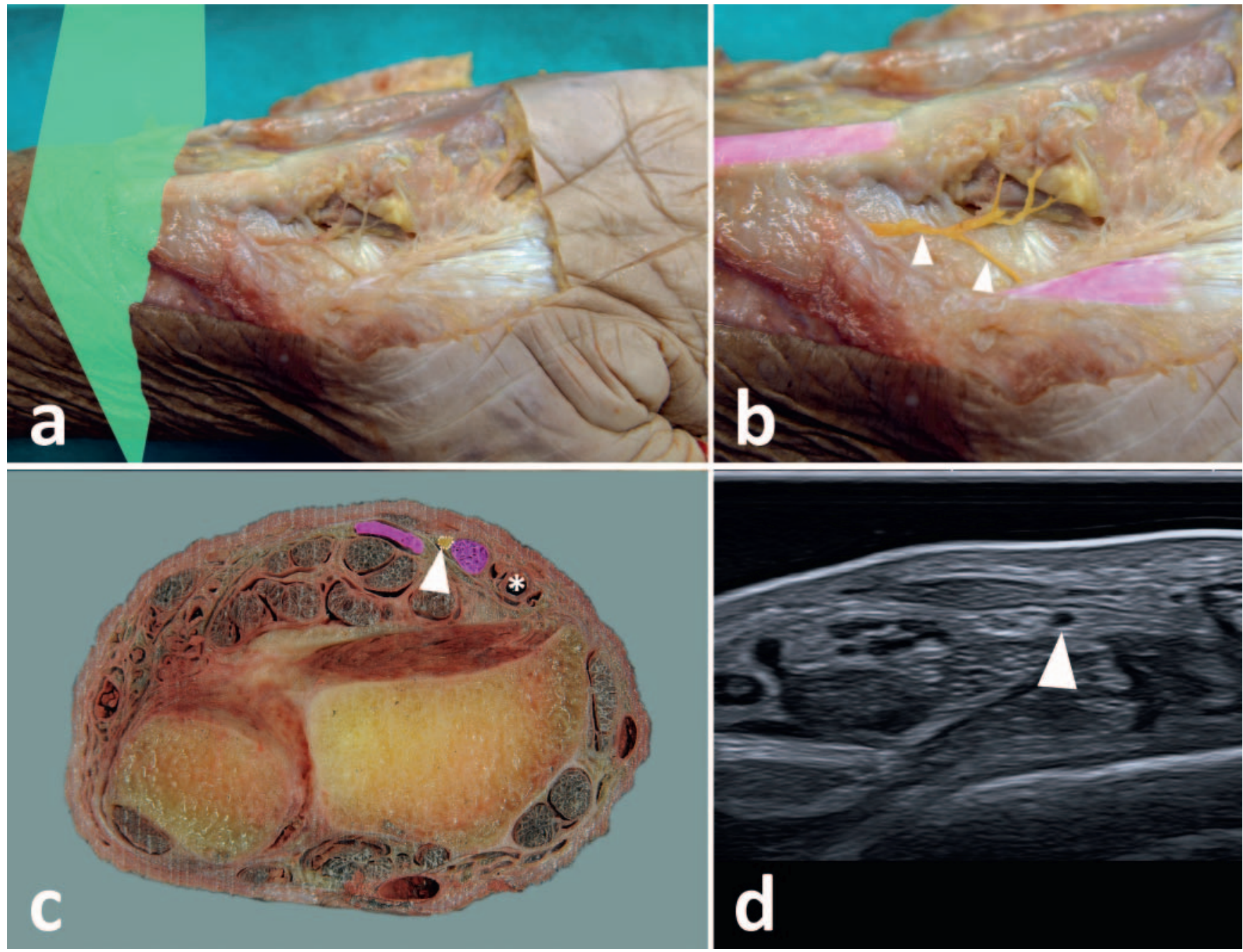

- Fig. 4 Palmar branch of the median nerve: anatomical preparation overview a, color-highlighted magnification b, anatomical cross-section c, and corresponding high-resolution ultrasound image $\mathbf{d}$. The palmar branch of the median nerve (yellow, white arrowhead) can be found between the tendon of the long palmar muscle (purple, ulnar) and radial carpal flexor (purple, radial).

- Abb. 4 Ramus palmaris N. medianus: anatomische Präparation a, eingefärbte Vergrößerungsaufnahme b, anatomischer Schnitt c, korrespondierendes hochauflösendes Ultraschallbild $\mathbf{d}$. Der Ramus palmaris N. medianus (gelb, weißer Pfeilkopf) kann zwischen den Sehnen des M. palmaris longus (violett, ulnar) und des M. flexor carpi radialis aufgefunden werden.

\section{Median nerve}

The palmar branch leaves the median nerve at the distal forearm, runs alongside its main stem under the radial edge of the palmaris longus tendon and penetrates the palmar aponeurosis. In its proximal course, it is radially surrounded by the flexor carpi radialis tendon, radial artery and the palmaris longus muscle as well as the tendons of the superficial finger flexor on the ulnar side and can be found by placing the transducer $3-5 \mathrm{~cm}$ proximal of the linea carpi ( $\triangleright$ Fig. 4$)$.

After passing the carpal tunnel, the median nerve divides into the $1^{\text {st }}$ to $3^{\text {rd }}$ common palmar finger nerves ( $\bullet$ Fig. 5). There are anastomoses between the deep branch of the ulnar nerve and motor branches of the median nerve, also called Riche-Cannieuanastomosis [12].

Either originating from the median nerve or from the first common finger nerve, the thenar branch usually can be located by placing the transducer over and parallel to the thenar crease, even though the thenar branch's origin and course are highly variable. In the carpal tunnel, the small thenar branch (approx. $1 \mathrm{~mm}^{2}$ ) is anteriorly surrounded by the transverse ligament, radially by the tendon of the flexor carpi radialis muscle and deeper by the tendon of the long flexor pollicis muscle. On the ulnar side, the common finger nerves, originating from the median nerve, accompany it ( $\bullet$ Fig. $\mathbf{5}$ ). Before entering the thenar musculature, the thenar branch may loop back over the transverse ligament in a superficial segment.

\section{Ulnar nerve}

The ulnar nerve enters Gyon's canal at the height of the distal carpi palmaris crease between the pisiform bone and the hamulus of the hamate bone [13] and reaches the palm of the hand after splitting into the deep motor branch and the superficial sensory 

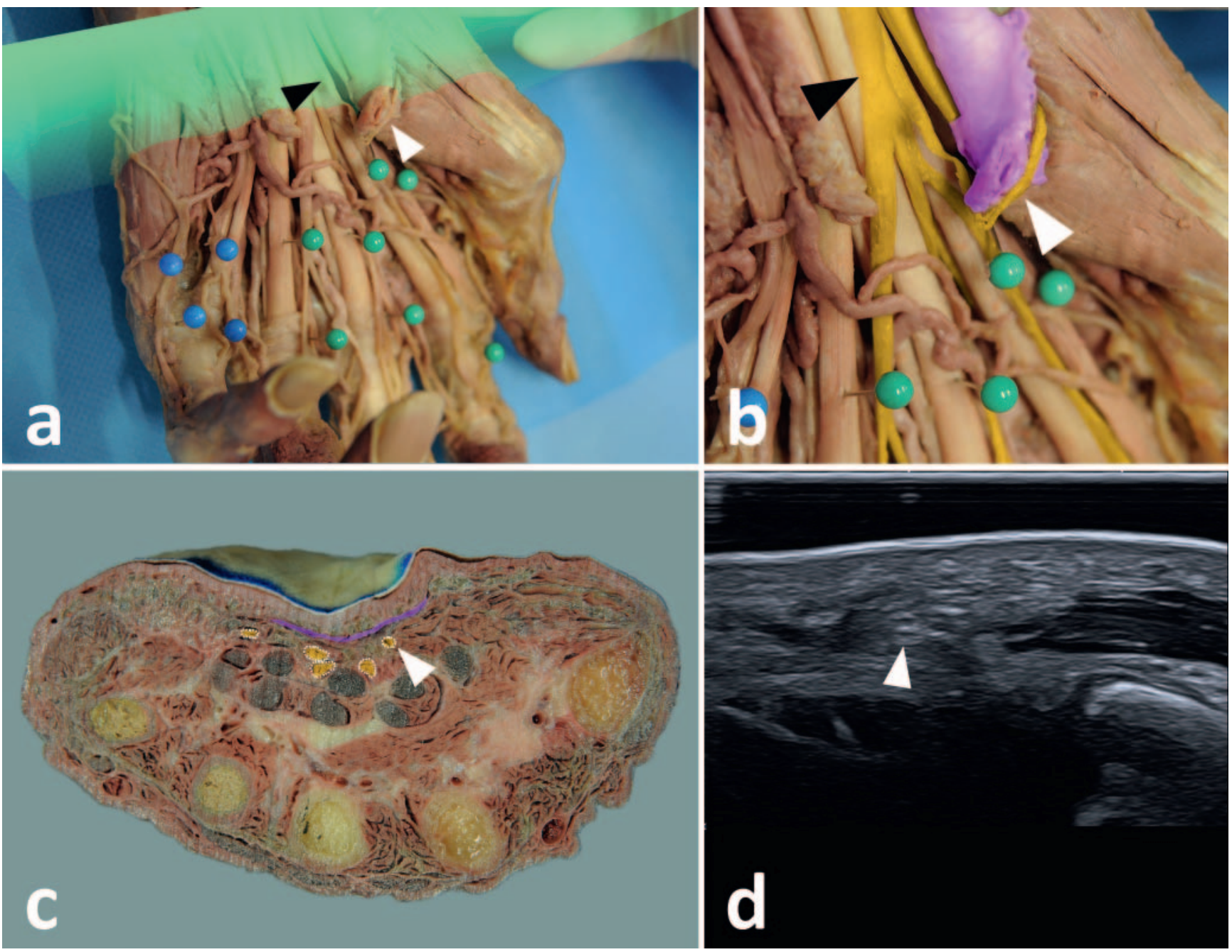

- Fig. 5 Thenar branch of the median nerve: anatomical preparation overview a, color-highlighted magnification b, anatomical cross-section c, and corresponding high-resolution ultrasound image $\mathbf{d}$. The thenar branch (yellow, white arrowhead) shows a variable course through or around the transverse ligament (purple). The common finger nerves can also be identified (c, yellow).

- Abb. 5 Thenarer Ast des N. medianus: anatomische Präparation a, eingefärbte Vergrößerungsaufnahme b, anatomischer Schnitt c, korrespondierendes hochauflösendes Ultraschallbild $\mathbf{d}$. Der thenare Ast hat einen variablen Verlauf durch und um das Ligamentum transversum (violett). Die Nn. digitales palmares communes sind mit abgebildet (c, gelb).

branch before or within Gyon's canal [10]. The palmar aponeurosis and the palmaris brevis muscle form the medial, the flexor retinaculum the dorsal and the pisiform bone the ulnar-sided walls of Gyon's canal ( $\triangleright$ Fig. 6). Within Gyon's canal, the branches or the main stem are accompanied by the superficial branch of the ulnar artery. The contents of Gyon's canal can easily be visualized by placing the transducer on the pisiform bone at the linea carpis palmaris distalis.

Distal to the Gyon's canal, the superficial structures lie on the pisohamate ligament, while the deep branch runs under the pisohamate ligament and between the abductor digiti minimi and short flexor digiti minimi muscles. Here rare compression syndromes can occur due to crossing vascular branches of the accompanying deep palmar arch [14] ( Fig. 6). Both branches can be found at the outlet of Gyon's canal distal to the pisiform bone. The deep branch is usually accompanied by the deep palmar arch originating from the ulnar artery. The superficial branch can most easily be identified at its entry into the thenar musculature at the palmaris brevis muscle.

The sensory dorsal branch of the ulnar nerve ( $\vee$ Fig. 7 ) originates at the middle of the forearm and runs superficially on the back of the forearm covered by superficial veins, where it innervates the dorsal skin of the lateral half of the $4^{\text {th }}$ and the $5^{\text {th }}$ finger [10]. It can be found by placing the transducer at the ulnar edge of the forearm 3-5 cm proximal to the ulnar head.

The palmar branch of the ulnar nerve arises approximately $5 \mathrm{~cm}$ to the Gyon's canal and runs alongside the ulnar nerve ( $\triangleright$ Fig. 8). It provides sensory innervation to the hypothenar skin.

\section{Common and proper finger nerves}

The median nerve branches into three and the ulnar nerve into two common finger nerves. The flexor retinaculum and the palmar aponeurosis form the superficial border for all common fin- 


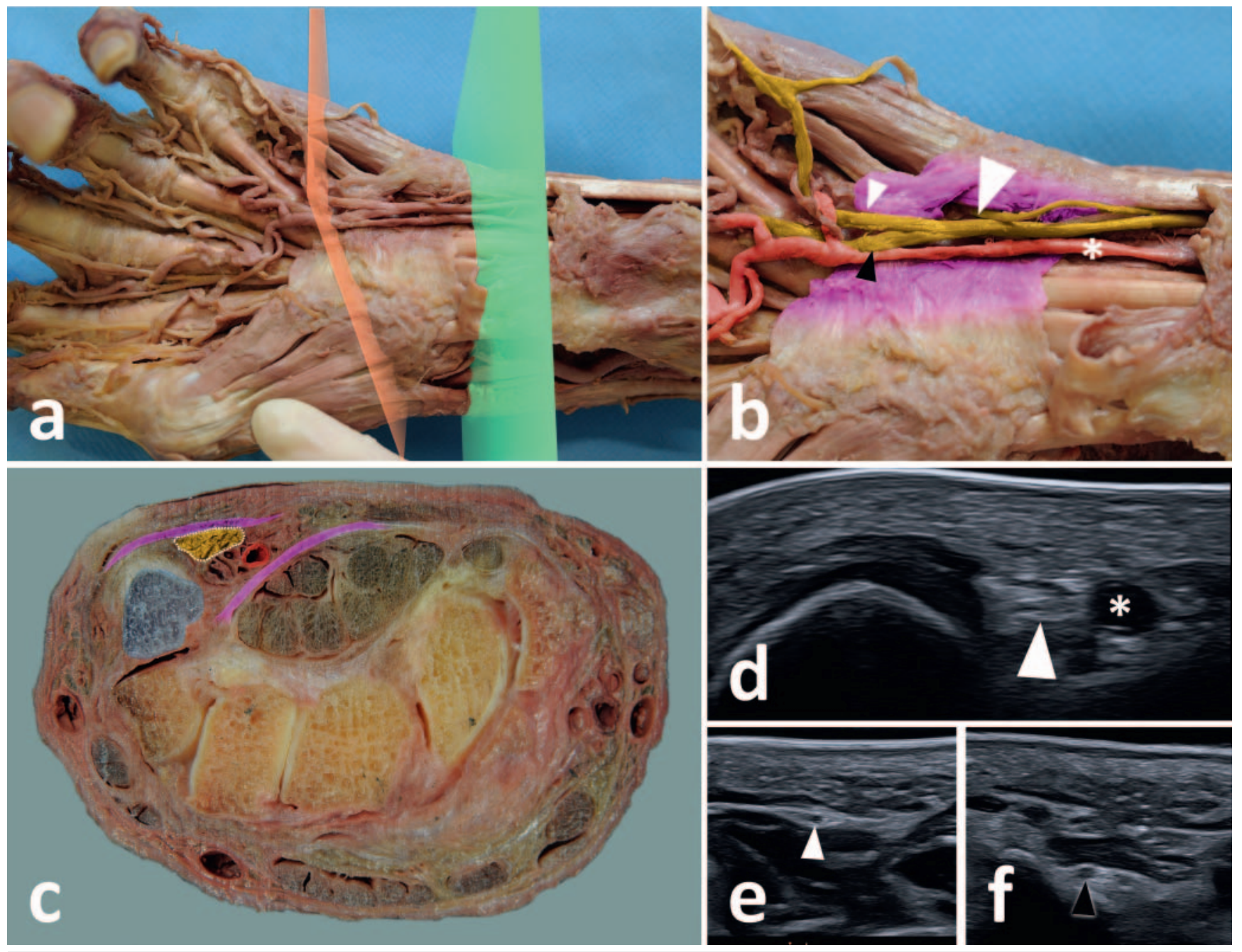

- Fig. 6 Gyon's canal: anatomical preparation overview including proximal (green) and distal (orange) cutting plane a, color-highlighted magnification b, anatomical cross-section c, and corresponding high-resolution ultrasound images $\mathbf{d}$-f. Within Gyon's canal, the ulnar nerve (yellow, white arrowhead) is accompanied by the ulnar artery $\left(\right.$ red, ${ }^{*}$ ). It then divides into the superficial (e, small white arrowhead) and deep branch (f, small black arrowhead).

- Abb. 6 Gyon'sche Loge: anatomische Präparation mit proximaler (grün) und distaler (orange) Schnittebene a, eingefärbte Vergrößerungsaufnahme b, anatomischer Schnitt c, korrespondierende hochauflösende Ultraschallbilder d-f. Innerhalb der Guyon'schen Loge wird der N. ulnaris (gelb, weißer Pfeilkopf) von der A. ulnaris begleitet (rot, ${ }^{*}$ ). Dann zweigt er sich in einen oberflächlichen (e, kleiner weißer Pfeilkopf) und einen tiefen Ast (f, kleiner schwarzer Pfeilkopf) auf.

ger nerves, while the finger flexor tendons run under the first three nerves. The remaining two common finger nerves can be found anterior to the pisohamate ligament ( $\bullet$ Fig. 9).

At the height of the distal transverse ligament, the common finger nerves split into the proper finger nerves. Three proper finger nerves arise from the first common finger nerve, innervating the skin of the thumb and the radial side of the index finger. The other common finger nerves each divide into two proper finger nerves, innervating the radial and ulnar-sided skin of two adjacent fingers.

To visualize the proper finger nerves, the transducer should be placed on the proximal phalanges, where the nerves can be found alongside the finger vessels ( $\bullet$ Fig. 10 ).
Transducer positions and anatomical landmarks for the nerves of the forearm, wrist and hand are summarized in $\triangleright$ Table 1.

\section{Evaluation of landmarks in healthy volunteers}

Following the proposed landmark-based approach, a detection rate of $100 \%$ could be achieved for all nerves and nerve branches except for the thenar branch of the median nerve. Here, only $45 \%$ could be detected in right arms and $35 \%$ in left arms ( $\triangleright$ Table 2 ). No influence of age or sex on the detection rate could be demonstrated. 

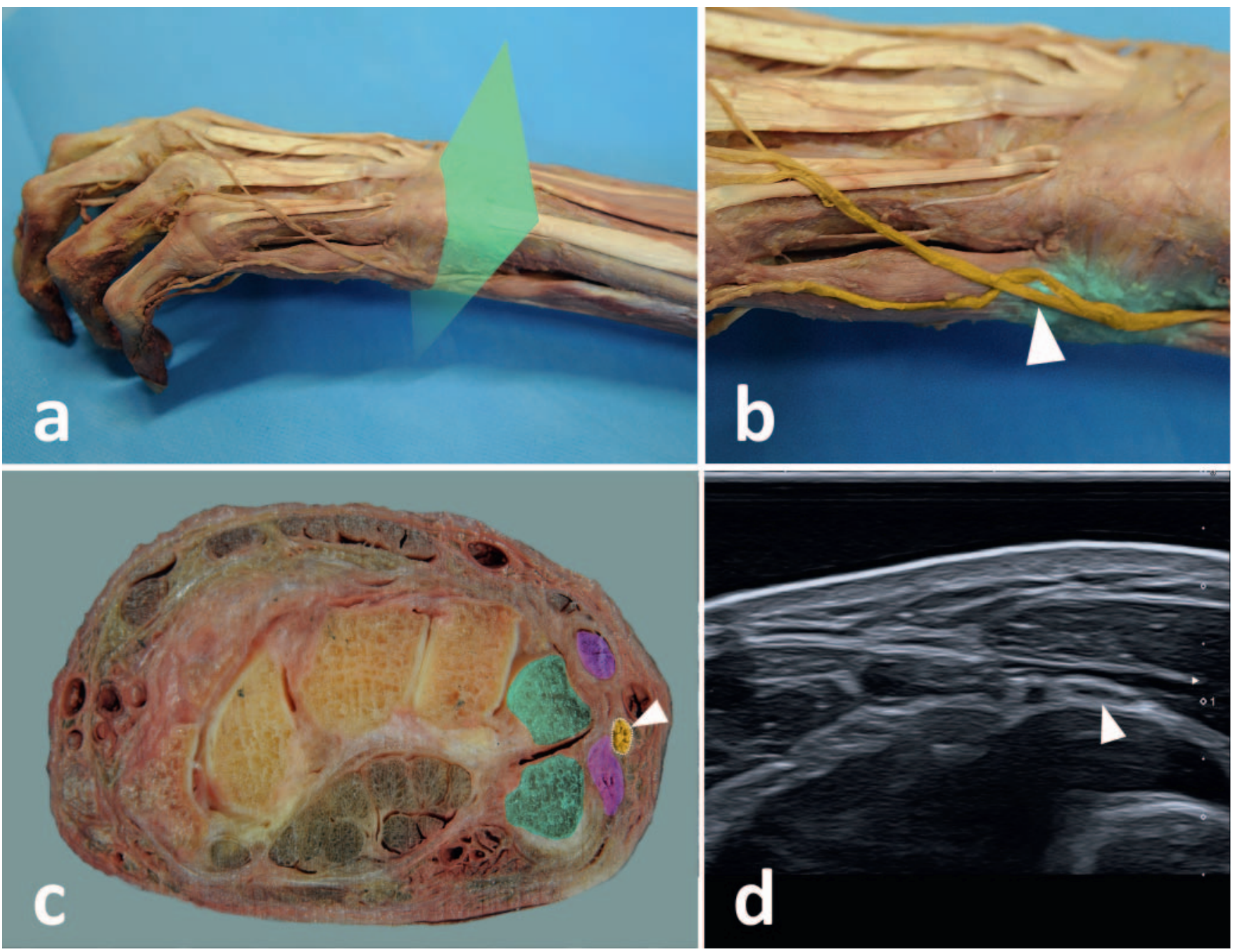

- Fig. 7 Dorsal branch of the ulnar nerve: anatomical preparation overview a, color-highlighted magnification b, anatomical cross-section c, and corresponding high-resolution ultrasound image $\mathbf{d}$. The dorsal branch of the ulnar nerve (yellow, white arrowhead) can be found covered by superficial veins and on top of the tendons of the ulnar carpal extensor and extensor digiti minimi (purple) at the height of the pisiform and triquetrum (turquoise).

- Abb.7 Ramus dorsalis N. ulnaris: anatomische Präparation a, eingefärbte Vergrößerungsaufnahme b, anatomischer Schnitt c, korrespondierendes hochauflösendes Ultraschallbild d. Der Ramus dorsalis N. ulnaris (gelb, weißer Pfeilkopf) wird von oberflächlichen Venen bedeckt und kann über den Sehnen des M. extensor carpi ulnaris und M. extensor digiti minimi (violett) auf Höhe des Os pisiforme und triquetrum (türkis) aufgefunden werden.

\section{Discussion}

Nerve damage of the forearm, wrist and hand can occur for various reasons like trauma, compression syndromes and tumors $[5,15]$. Exact location identification and evaluation of small nerve lesions is complicated by complex topography, small structure scale and oftentimes subtle neural alterations. Thus, the learning curve for radiologists in the area of nerve sonography is considered steeper than, for example, via MRI [16]. While correct and timely diagnosis is essential for a patient's outcome [17, 18], especially correct location identification can be time-consuming if following the nerves from a proximal segment, particularly if proximal segments of a given nerve cannot be visualized due to masking or lack of ultrasound penetration. Therefore, the relation of nerves and landmarks can be used for quicker identification of small nerve branches [19].

In this sonoanatomic study, we could demonstrate that the use of predefined landmarks is a valid and reproducible tool for the identification and evaluation of small nerve branches. Almost all nerve branches we examined had a high detection rate. Only the thenar branch of the median nerve could be detected in less than half of wrists. A standardized approach relying on landmarks further requires less experience in finding nerve branches and should speed up learning in residents.

The most common causes of peripheral nerve lesions are compression neuropathies and trauma $[16,18]$. Neoplasms and inflammatory states occur less frequently [16]. HRUS allows for dynamic examinations and targeted provocation of symptoms. 

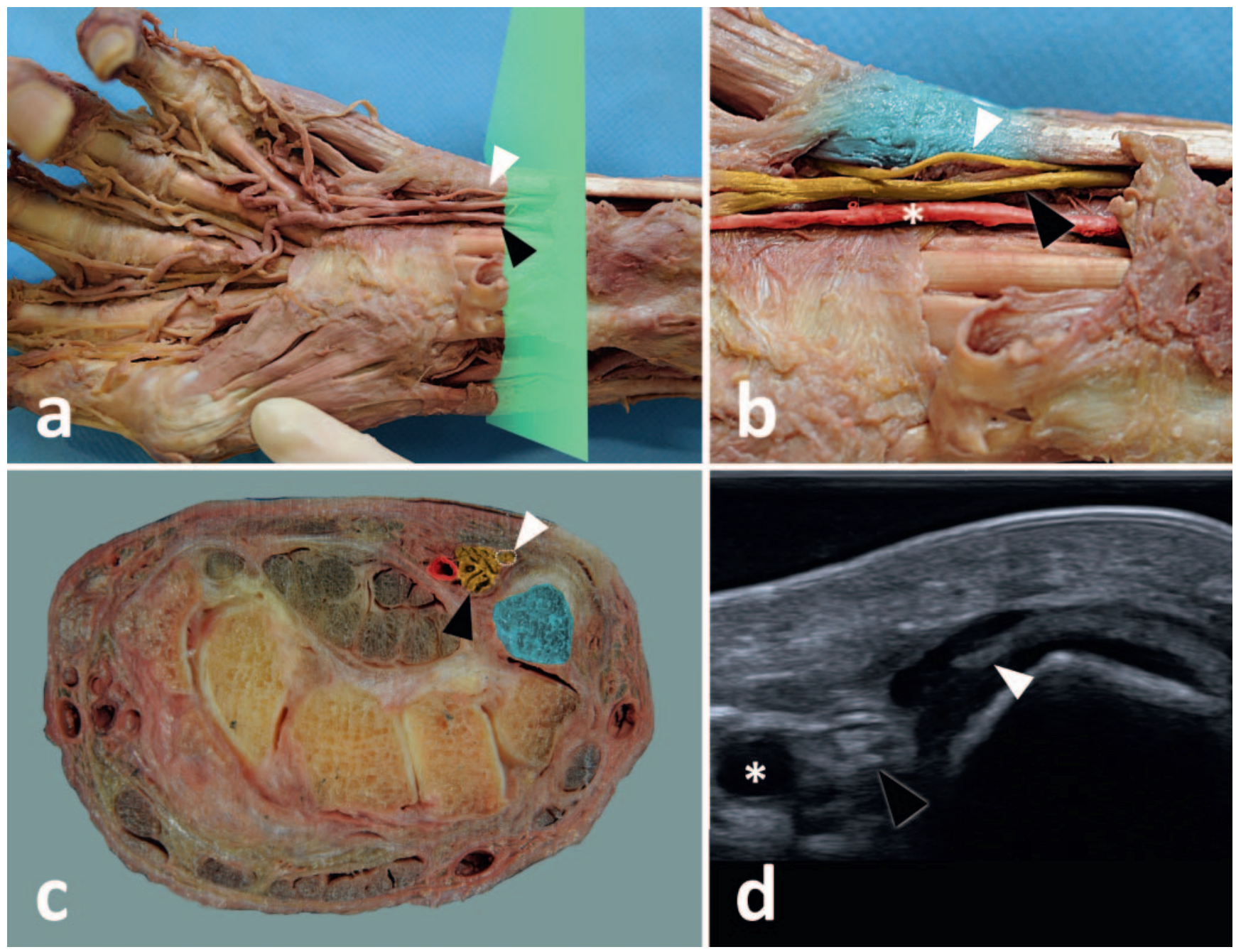

- Fig. 8 Palmar branch of the ulnar nerve: anatomical preparation overview a, color-highlighted magnification b, anatomical cross-section c, and corresponding high-resolution ultrasound image $\mathbf{d}$. The hypothenar branch (yellow, white arrowhead) can be found alongside the ulnar nerve (yellow, black arrowhead) in the carpal tunnel at the height of the pisiform (turquoise), accompanied by the ulnar artery (red, ${ }^{*}$ ).

- Abb. 8 Ramus palmaris N. ulnaris: anatomische Präparation a, eingefärbte Vergrößerungsaufnahme b, anatomischer Schnitt c, korrespondierendes hochauflösendes Ultraschallbild d. Der Ramus palmaris N. ulnaris (gelb, weißer Pfeilkopf) kann in der Guyon'schen Loge auf Höhe des Os pisiforme (türkis) neben dem N. ulnaris aufgefunden werden und wird von der A. ulnaris begleitet (rot, ${ }^{*}$ ).

Thus, a correlation between clinical presentation and sonomorphologic alterations is possible [20]. HRUS enables differentiation between neurapraxia/axonotmesis on the one hand and neurotmesis, i. e. complete discontinuity of the nerve on the other $[17,18$, 20]. Rapid diagnosis and treatment are essential especially in posttraumatic or iatrogenic nerve lesions [16]. Outcome rapidly worsens if delays occur in this early stage of nerve trauma $[17,18]$. Furthermore, HRUS can yield (preliminary) information on the nerve route, normal variants, the extent of the discontinuity and whether a graft will be needed [18].

Beyond purely diagnostic applications, HRUS enables sonographers to perform imaging-guided neural interventions. Diagnostic and therapeutic targeting and perineural injection of local anesthetics in patients with chronic pain [21] or phenol for the treatment of e. g. stump neuroma [22] are already routinely performed.

One limitation of this study is the low detection rate of the thenar branch - which can be damaged during carpal tunnel release surgery $[23,24]$ - in healthy volunteers. The definition of a singular landmark is complicated by its small cross-sectional area, highly variable origin and course [24]. Due to its exploratory nature and overall study design, no intra- or inter-observer correlation was performed. Only two cadaver arms were examined, thus anatomical variations were not included in this study. Furthermore, the healthy volunteers we examined were rather young. Nerve detection rates in the elderly, overweight or chronically ill may be lower. 

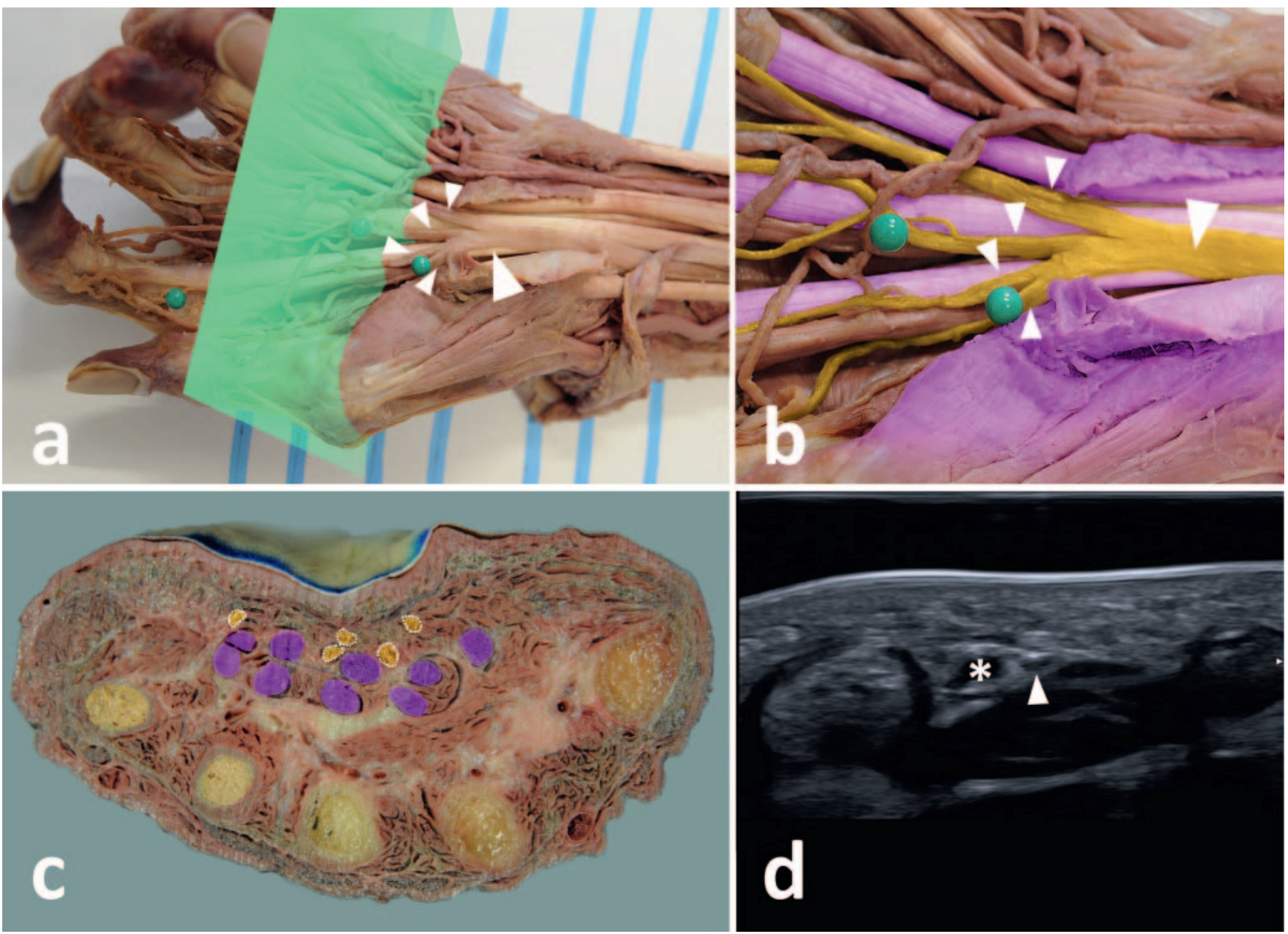

- Fig. 9 Common finger nerves: anatomical preparation overview a, color-highlighted magnification b, anatomical cross-section c, and corresponding high-resolution ultrasound image $\mathbf{d}$. The median nerve (yellow, large white arrowhead) gives off common finger nerves (yellow, small arrowheads), which run alongside the flexor tendons (purple) and are accompanied by respective common finger arteries. The retinaculum flexorum (purple) has been dissected.

- Abb.9 Nn. digitales palmares communes: anatomische Präparation a, eingefärbte Vergrößerungsaufnahme b, anatomischer Schnitt c, korrespondierendes hochauflösendes Ultraschallbild $\mathbf{d}$. Der N. medianus (gelb, großer weißer Pfeilkopf) gibt Nn. digitales palmares communes ab, die neben den Flexorensehnen (violett) verlaufen von den jeweiligen Fingerarterien begleitet werden. Das Retinaculum flexorum wurde gespalten (violett).

- Table 2 Detection rates of the various nerves and nerve segments in healthy volunteers following the proposed visualization guidelines.

- Tab.2 Detektionsraten der unterschiedlichen Nerven und Nervenäste an gesunden Probanden unter Verwendung der vorgeschlagenen Leitlinien.

\begin{tabular}{|l|l|l|l|}
\hline & & detection rate & left arm (\%) \\
\hline \multirow{2}{*}{ radial nerve } & nerve segment & right arm (\%) & 100 \\
\hline & superficial branch (proximal) & 100 & 100 \\
\hline ulnar nerve & superficial branch (distal) & 100 & 100 \\
\hline & dorsal branch & 100 & 100 \\
\hline median nerve & Gyon's canal & 100 & 35 \\
\hline \multirow{2}{*}{ median \& ulnar nerve } & thenar branch & 45 & 100 \\
\hline & palmar branch & 100 & 100 \\
\hline & common finger nerves & 100 & 100 \\
\hline
\end{tabular}



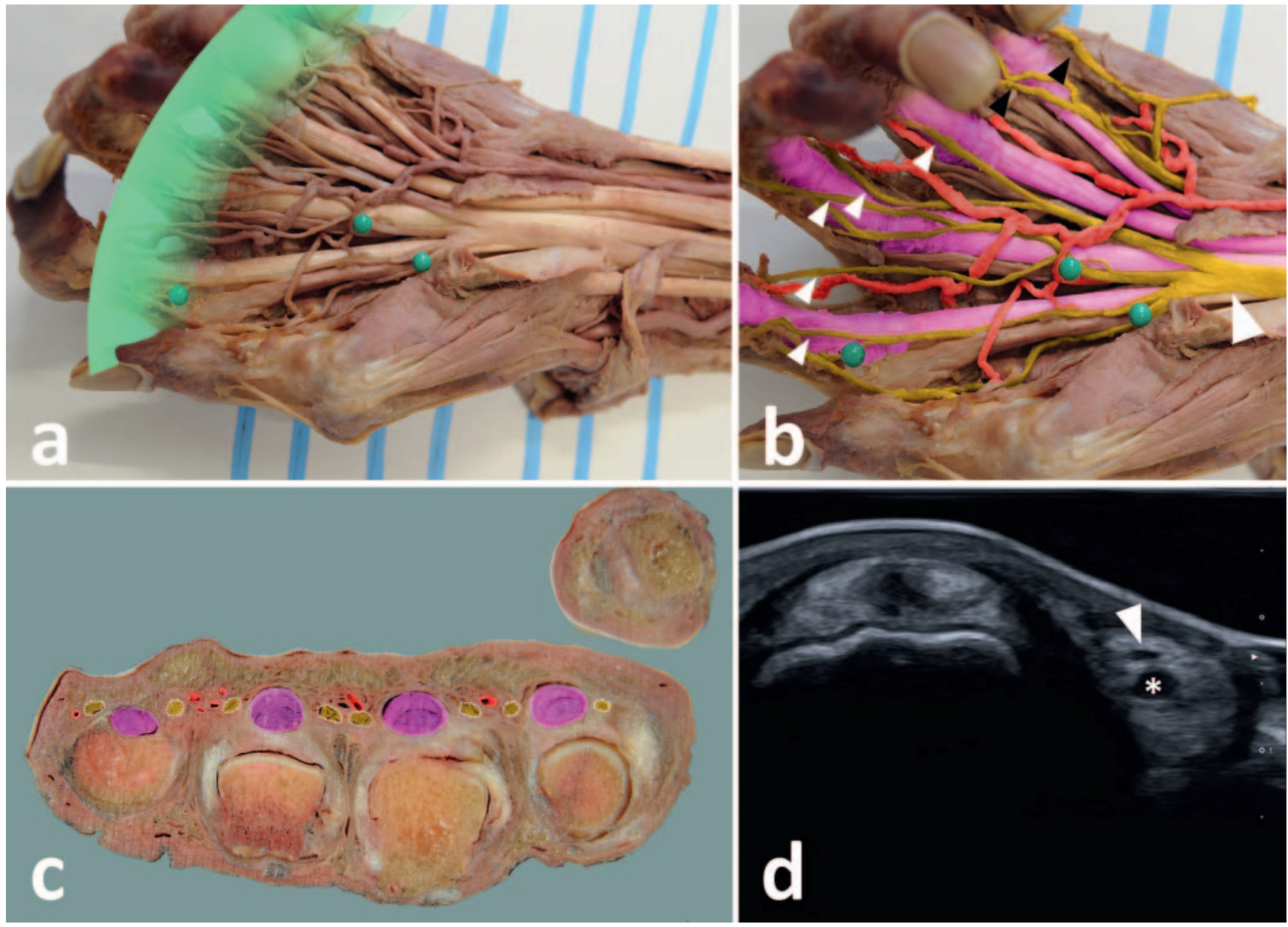

- Fig. 10 Proper finger nerves: anatomical preparation overview a, color-highlighted magnification b, anatomical cross-section c, and corresponding high-resolution ultrasound image $\mathbf{d}$. The proper finger nerves (yellow, small white arrowheads) arise from the common finger nerves (see also

- Fig. 9) and run on the ulnar and radial side of the flexor tendons (purple) and are accompanied by a small proper finger artery (red, ${ }^{*}$ ).

- Abb. 10 Nn. digitales palmares proprii: Nn. digitales palmares communes: anatomische Präparation a, eingefärbte Vergrößerungsaufnahme $\mathbf{b}$, anatomischer Schnitt c, korrespondierendes hochauflösendes Ultraschallbild d. Die Nn. digitales palmares proprii (gelb, kleiner weißer Pfeilkopf) werden von den $\mathrm{Nn}$. digitales palmares communes (siehe $>$ Abb. 9) gebildet und verlaufen auf der ulnaren und radialen Seite der Flexorensehnen (violett). Sie werden von kleinen Fingerarterien begleitet (rot, * $)$.

\section{Conclusion}

This sonoanatomic correlation study demonstrates the validity and reproducibility of standardized guidelines based on predefined anatomical landmarks in the detection of peripheral nerve branches of the hand and wrist. The findings should simplify and accelerate the location identification and diagnosis of peripheral nerve lesions of the forearm, wrist and hand with HRUS.

\section{CLINICAL RELEVANCE}

- Peripheral nerve pathologies can be assessed with highresolution ultrasound.

- Following the nerves from proximal to distal can be timeconsuming and difficult, especially in immobile patients.

- A landmark-based approach facilitates even the depiction of tiny nerves/nerve branches.

- Beyond purely diagnostic applications, high-resolution ultrasound enables sonographers to perform imagingguided interventions in real time. 


\section{Conflict of Interest}

The authors declare that they have no conflict of interest.

\section{References}

[1] Beekman R, Visser LH. High-resolution sonography of the peripheral nervous system - A review of the literature. Eur J Neurol 2004; 11: 305314

[2] Chung T, Prasad K, Lloyd TE. Peripheral neuropathy: clinical and electrophysiological considerations. Neuroimaging Clin N Am 2014; 24: 49-65

[3] Koenig RW, Pedro MT, Heinen CPG et al. High-resolution ultrasonography in evaluating peripheral nerve entrapment and trauma. Neurosurg Focus 2009; 26: E13

[4] Moritz T, Prosch H, Pivec CH et al. High-resolution ultrasound visualization of the subcutaneous nerves of the forearm: A feasibility study in anatomic specimens. Muscle Nerve 2014; 49: 676-679

[5] Tagliafico A, Cadoni A, Fisci E et al. Nerves of the hand beyond the carpal tunnel. Semin Musculoskelet Radiol 2012; 16: 129-136

[6] McHanwell S, Brenner E, Chirculescu ARM et al. The legal and ethical framework governing Body Donation in Europe - A review of current practice and recommendations for good practice. Eur J Anat 2008; 12 : $1-24$

[7] Brenner E. Human body preservation - old and new techniques. J Anat 2014; 224: 316-344

[8] Platzer W, Putz R, Poisel S. New system for the preservation and storage of anatomical matter. Acta Anat (Basel) 1978; 102: 60-67

[9] WMA General Assembly. World Medical Asssociation Declaration of Helsinki: Ethical Principles for Medical Research Involving Human Subjects (as amended by the 59th WMA General Assembly, Seoul, October 2008). In: World Medical Association 2008

[10] Frotscher M, Kahle W. Taschenatlas Anatomie, Band 3: Nervensystem und Sinnesorgane. $11^{\text {th }}$ ed Leipzig, Germany: Thieme; 2013

[11] Loukas M, Louis RG, Wartmann CT et al. The clinical anatomy of the communications between the radial and ulnar nerves on the dorsal surface of the hand. Surg Radiol Anat 2008; 30: 85-90
[12] Wali A, Ahmed R, Khan S. Electrophysiological evidence of the RicheCannieu anastomosis in the hand and its diagnostic implications; 2 case reports. Clin Neurophysiol Pract 2017; 2: 8-11

[13] Maroukis BL, Ogawa T, Rehim SA et al. Guyon canal: The evolution of clinical anatomy. J Hand Surg Am Elsevier Inc 2015; 40: 560-565

[14] Gruber L, Gruber H, Bauer T et al. A rare case of a punched nerve syndrome of the deep motor branch of the ulnar nerve. Arch Orthop Trauma Surg 2015; 135: 891-893

[15] Kopf H, Loizides A, Mostbeck G et al. Diagnostische Sonografie peripherer Nerven: Indikationen, Techniken und Pathologien. Eur J Ultrasound 2011; 32: 242-266

[16] Chiou H], Chou YH, Chiou SY et al. Peripheral nerve lesions: role of highresolution US. Radiographics 2003; 23: e15

[17] Kowalska B, Sudoł-Szopińska I. Ultrasound assessment of selected peripheral nerve pathologies'. Part III: Injuries and postoperative evaluation. J Ultrason 2013; 13: 82-92

[18] Lauretti L, D'Alessandris QG, Granata G et al. Ultrasound evaluation in traumatic peripheral nerve lesions: from diagnosis to surgical planning and follow-up. Acta Neurochir (Wien) 2015; 157: 1947-1951

[19] Canella C, Demondion X, Guillin R et al. Anatomic study of the superficial peroneal nerve using sonography. Am J Roentgenol 2009; 193: 174-179

[20] Kowalska B. Assessment of the utility of ultrasonography with highfrequency transducers in the diagnosis of entrapment neuropathies. J Ultrason 2014; 14: 371-392

[21] Ali ZS, Pisapia JM, Ma TS et al. Ultrasonographic Evaluation of Peripheral Nerves. World Neurosurg Elsevier Inc 2016; 85: 333-339

[22] Gruber H, Kovacs P, Peer S et al. Sonographically guided phenol injection in painful stump neuroma. Am J Roentgenol 2004; 182: 952-954

[23] Sacks JM, Kuo YR, Mclean K et al. Anatomical Relationships among the Median Nerve Thenar Branch, Superficial Palmar Arch, and Transverse Carpal Ligament. Plast Reconstr Surg 2007; 120: 713-718

[24] Henry BM, Zwinczewska H, Roy J et al. The prevalence of anatomical variations of the median nerve in the carpal tunnel: A systematic review and meta-analysis. PLoS One 2015; 10: 1-18 